\title{
Pelaksanaan Peran Kantor Wilayah Kementerian Hukum Dan Ham Sumatera Barat Dalam Rangka Harmonisasi Peraturan Daerah Provinsi Sumatera Barat Tahun 2019
}

\author{
Alsyam $^{1}$, Delfina Gusman², Didi Nazmi ${ }^{3}$ \\ 1.Fakultas Hukum, Universitas Andalas, Indonesia.E-Mail: alsyam1162@gmail.com \\ 2. Fakultas Hukum, Universitas Andalas, Indonesia. E-Mail: vivin.nissa@yahoo.com \\ 3. Fakultas Hukum, Universitas Andalas, Indonesia. E-Mail: didinazmi@yahoo.com,
}

\begin{abstract}
The Regional Offices of the Ministry of Law and Human Rights in each region have an important role in the harmonization of regional regulations in accordance with the legal hierarchy. Harmonization of law is an effort to create a harmony, suitability and compatibility to balance the legal norms. One of the agencies that has this role is the Ministry of Law and Human Rights to each region. The results of the study show that in relation to the duties and functions of the Regional Office, basically the duties and functions of the Regional Office in preparing regional regulations are in line with the provisions of Law Number 12 of 2011 concerning the Establishment of Legislation. the invitation, but the involvement of the Regional Office of the Ministry of Law and Human Rights is limited and passive waiting for the local government and DPRD to participate. In an effort to increase the role of the Regional Office of the Ministry of Law and Human Rights in the process of drafting regional regulations, it is necessary to formulate a rule for implementation that regulates in detail the mechanism for the preparation of regional regulations involving the Regional Government, DPRD and Regional Office of the Ministry of Law and Human Rights. optimizing the preparation of quality regional regulations.
\end{abstract}

Keywords: Harmonization of Regulation, Regional Regulation Composing, Regional office of the Ministry of Law and Human Right.

\section{Pendahuluan}

Kantor Wilayah Kementerian Hukum dan HAM Sumatera Barat merupakan instansi vertikal Kementerian Hukum dan HAM Republik Indonesia yang berkedudukan di Propinsi yang berada di bawah dan bertanggungjawab kepada Menteri Hukum dan Hak Asasi Manusia Republik Indonesia. Peran Kantor Wilayah Kementerian Hukum dan HAM Sumatera Barat dalam proses pengharmonisasian Peraturan Daerah dilakukan secara tim dengan diskusi yang terdiri dari Kantor Wilayah Kementerian Hukum Dan HAM Sumatera Barat, Biro Hukum Provinsi, Akademisi dan Aparat Penegak Hukum. Hasil yang didapat dari kegiatan ini diharapkan dapat menjadi masukan bagi Pemerintah Daerah dalam penyusunan Peraturan Daerah agar tidak bertentangan dengan Peraturan Perundangundangan yang lebih tinggi dan dapat mengakomodir aspirasi masyarakat.

Harmonisasi hukum adalah upaya atau proses yang hendak mengatasi batasan-batasan perbedaan, hal-hal yang bertentangan dan kejanggalan dalam. Upaya atau proses merealisasi keselarasan, kesesuaian, keserasian, kecocokan, keseimbangan diantara norma-norma hukum di dalam peraturan perundangan-undangan sebagai sistem hukum. 
Harmonisasi hukum dapat juga diartikan sebagai upaya proses penyesuaian asas dan sistem hukum, agar terwujud kesederhanaan hukum, kepastian hukum dan keadilan.

Harmonisasi hukum sebagai suatu proses dan pembentukan peraturan perundangundangan, mengatasi hal-hal yang bertentangan dan kejanggalan diantara norma-norma hukum di dalam peraturan perundang-undangan, sehingga terbentuk peraturan perundang-undangan nasional yang harmonis, dalam arti selaras, serasi, seimbang, terintegritas, dan konsisten, serta taat asas. Langkah sistematik harmonisasi hukum nasional, bertumpu pada paradigma Pancasila dan UUD 1945 yang melahirkan sistem ketatanegaraan dengan dua asas fundamental, asas demokrasi dan asas negara hukum yang diidealkan mewujudkan sistem hukum nasional dengan tiga komponen, yaitu substansi hukum, struktur hukum beserta kelembagaannya, dan budaya hukum.

Di dalam suatu sistem hukum yang terdiri dari peraturan perundang-undangan sebagai sub sistem yang saling terkait tidak dapat berdiri sendiri terlepas dari sistem hukum tersebut. Harmonisasi peraturan perundang-undangan mempunyai peranan yang sangat penting dalam menjaga keselarasan dan mencegah tumpang tindihnya peraturan perundang-undangan yang satu dengan yang lain yang dapat mengakibatkan terciptanya kondisi ketidakpastian hukum sehingga dapat menjamin tercapainya tujuan hukum yakni mengabdikan kepada tujuan Negara untuk menciptakan kesejahteraan dan kebahagiaan bagi rakyatnya.

Mengingat hierarki peraturan perundang-undangan dan asas hukum yang berlaku, maka terdapat beberapa beberapa jenis harmonisasi peraturan perundang-undangan. Harmonisasi vertikal, yakni harmonisasi perundang-undangan yang dilakukan terhadap peraturan perundang-undangan yang lain dalam hierarki yang berbeda. Harmonisasi horizontal, yakni harmonisasi peraturan perundang-undangan yang dilakukan terhadap peraturan perundang-undangan yang berada dalam hierarki yang sama dan sederajat.

Tanpa adanya harmonisasi sistem hukum akan memunculkan keadaan tidak dapat menjamin kepastian hukum yang dapat menimbulkan gangguan dalam kehidupan bermasyarakat, ketidaktertiban dan rasa tidak dilindungi. Dalam perspektif demikian masalah kepastian hukum akan dirasakan sebagai kebutuhan yang hanya dapat terwujud melalui harmonisasi sistem hukum. ${ }^{1}$ Dalam perpektif demikian, langkah untuk menuju harmonisasi hukum dapat dilakukan dalam dua langkah perumusan, yaitu harmonisasi kebijakan formulasi (sistem pengaturan) dan harmonisasi materi (subtansi). Untuk hal pertama menunjuk pada langkah perumusan harmonisasi sistem hukumnya, dan hal kedua menunjuk pada langkah perumusan harmonisasi norma-norma (materi hukum).

Perumusan langkah yang ideal yang ditempuh dalam harmonisasi sistem hukum adalah sebagaimana dikemukakan oleh L. Friedmann yaitu perlu melakukan penyesuaian unsurunsur tatanan hukum yang berlaku dalam kerangka sistem hukum nasional (legal system) yang mencakup komponen materi hukum (legal substance), komponen struktur hukum beserta kelembagaannya (legal structure) dan komponen budaya hukum (legal culture).

\footnotetext{
${ }^{1}$ Kusnu Goesniadhie, Harmonisasi Hukum Dalam Persfektif perundang-undangan; Lex Specialis Suatu Masalah, (Surabaya; JP Books, 2006), hal. 100.
} 
Dengan demikian harmonisasi sistem hukum nasional melibatkan mata rantai hubungan ketiga komponen sistem hukum tersebut dalam kerangka sistem hukum nasional. ${ }^{2}$

Banyaknya peraturan daerah yang dibatalkan oleh Kementerian Dalam Negeri pada tahun 2016 yaitu 3.143 perda, termasuk juga Perda Provinsi Sumatera Barat. Salah satu alasan kuatnya pembatalan perda-perda tersebut karena tidak sinkron lagi dengan peraturan perundang-undangan yang lebih tinggi. Hal ini terjadi salah satunya sejauh mana peran Kanwil Hukum dan HAM Sumatera Barat melakukan harmonisasi perda terhadap peraturan perundang-undangan yang lebih tinggi.

\section{Metode}

Penelitian ini menggunakanan metode penelitian kualitatif. Penelitian kualitatif merupakan penelitian yang dilakukan untuk mencari makna, pemahaman, pengertian tentang suatu fenomena, kejadian, maupun kehidupan manusia dalam setting atau latar alamiah, kontekstual dan menyeluruh. Dalam hal ini, peneliti kualitiaitif berupaya mengerti makna dari suatu peristiwa. Pemahaman makna tentang sesuatu dalam penelitian kualitatif selalu menempatkan subjek penelitian dalam posisi yang sama dengan peneliti(Yusuf, ).

Penelitian kualitatif lebih bersifat deskriptif, sehingga disebut juga dengan deskriptif kualitatif. Penelitian dengan format deskriptif kualitatif (Bungin,2017) bertujuan untuk menggambarkan, meringkas berbagai kondisi atau realitas sosial yang ada di masyarakat yang menjadi objek penelitian. Penelitian ini menggunakan metode kualitatif karena bertujuan untuk memberikan deskripsi dan mengungkapkan makna serta melihat proses tentang pembinaan masyarakat pesisir yang dilakukan oleh staf Potmar Lanal Babel, dimana pembinaan yang dilakukan berbasis budaya lokal dalam mendukung pertahanan negara.

Sumber data pada penelitian ini terdiri dari data primer dan data sekunder. Data Primer merupakan sekumpulan infomasi yang diperoleh secara langsung dari informan berdasarkan wawancara dan hasil observasi yang dilakukan oleh peneliti. Data sekunder merupakan sekumpulan data yang diperoleh peneliti secara tidak langsung, yaitu data atau informasi yang telah dikumpulkan oleh orang lain (Martono,2015). Data sekunder diperoleh melalui berbagai tulisan yang relevan dengan penelitian.

Pada penelitian kualitatif, instrument penelitian utama adalah manusia, yaitu peneliti. Peneliti dapat meminta bantuan orang lain untuk membantu melakukan wawancara yang disebut dengan pewawancara (Afrizal,2014). Dalam mengumpulkan data di lapangan, peneliti memerlukan instrumen tambahan yang dapat membantu pengumpulan data lebih efektif. Instumen tersebut dapat berupa pedoman wawancara, alat perekan, alat tulis, kamera untuk dokumentasi kegiatan, dan alat-alat lainnya yang relevan. Teknik pengumpulan data pada penelitian ini dilakukan dengan cara observasi, wawancara dan studi kepustakaan. Sedangkan, pengolahan data dilakukan dengan menggunakan model pengolahan data Miles and Hubeman melalui Langkah-langkah sebagai berikut, yaitu: reduksi data, display data, dan verifikasi data (Sugiyono, 2012:92).

\footnotetext{
2 Ibid, hal. 84-85.
} 


\section{Hasil dan Pembahasan}

\section{Peran Kantor Wilayah Kementerian Hukum dan HAM Sumatera Barat Dalam Rangka Harmonisasi Peraturan Daerah Provinsi Sumatera Barat.}

Begitu banyak permasalahan muncul di berbagai negara berkembang maupun negara maju, dikarenakan tatanan kehidupan tidak lagi berjalan di atas rel atau alur yang seharusnya. Hal ini tentunya akan menimbulkan berbagai pergeseran nilai, pada mulanya hukum kodrat dapat menyelesaikan semua problem tersebut. Namun oleh karena kemajuan zaman dan teknologi, pertikaian ideologi maupun fisik antar individu atau kelompok tidak dapat terhindarkan lagi. ${ }^{1}$ Sehingga apabila salah satu merasa dirugikan tentunya akan membawa hal ini ke jalur hukum. Sesuai amanat konstisusi negara kita dalam Pasal 1 ayat 3 UUD 1945 mengatakan bahwa Indonesia adalah Negara Hukum.

Sebagai negara yang berdasarkan atas hukum (rechtsstaat), yang aspek legalitasnya menjadi unsur elementer yang harus dipenuhi maka seluruh aspek penyelenggaraan pemerintah wajib mendasarkan pada peraturan perundang-undangan. Dalam wilayah peraturan perundang-undangan di Indonesia, Peraturan Daerah sesuai dengan jenis hierarkinya dalam Pasal 7 ayat (1) Undang-Undang Nomor 12 Tahun 2011 adalah berada dalam UU, PP, dan Perpres. Namun demikian belum ada keseragaman pendapat di antara para pakar dan ahli mengenai siapa sebenarnya yang berwenang menguji peraturan daerah.

Perdebatan para ahli sesungguhnya pada wilayah berlakunya executive review dan judicial review terhadap Peraturan Daerah. Hal ini kemudian dilihat dari perspektif Undang-Undang Nomor 32 Tahun 2001 tentang Pemerintahan Daerah dan UndangUndang Nomor 12 Tahun 2011 tentang Pembentukan Peraturan Perundang-undangan berikut peraturan tentang hukum acara pengujian peraturan perundang-undangan menjadi referensi utama dalam kajian sekaligus analisis dalam membedah masalah pengujian Peraturan Daerah.

Salah satu lembaga yang sangat potensial dalam menjalankan roda pemerintahan dibidang hukum adalah Kementerian Hukum dan HAM. Pengaruh Kementerian Hukum da HAM sangat penting diantaranya dalam pembentukan produk hukum Nasional dan menjaga penerapan serta pemberlakuan hukum secara sinergitas dan terstruktur baik di tingkat pusat maupun daerah.

Sebelum adanya reformasi organisasi administrasi dan finansial pada Badan Peradilan Umum dan Tata Usaha Negara berada di bawah Kementerian Hukum dan HAM (dahulu Departemen Hukum dan HAM) dan kewenangan teknis yudisial di bawah Mahkamah Agung. Adanya reformasi dibidang peradilan dan diamandemennya UUD 1945, maka kekuasaan kehakiman/yudikatif dipisahkan secara penuh dari kekuasaan eksekutif (dalam hal ini Kementerian Hukum dan HAM). Sebagai tindak lanjut dari amandemen UUD 1945, maka Pemerintah bersama DPR telah mengesahkan Undang-Undang No.4 tentang Kekuasaan Kehakiman yang mengamanatkan perlunya organisasi, administrasi dan finansial Mahkamah Agung dan badan peradilan di bawahnya menjadi dibawah kekuasaan Mahkamah Agung. 
Sebagai konsekuensi dari kebijakan tersebut, Presiden telah menetapkan Keputusan Presiden Nomor 21 Tahun 2004 tentang Pengalihan organisasi, administrasi dan finansial di lingkungan Peradilan Umum, Peradilan Tata Usaha Negara serta Peradilan Agama di bawah Mahkamah Agung. Maka tugas pokok dan fungsi Kementerian Hukum dan HAM serta Kantor Wilayah yang merupakan instansi vertikal sebelum amandemen UUD 1945 dengan setelah amandemen UUD 1945 telah mengalami perubahan karena sudah tidak berkaitan lagi dengan penegakan hukum dibidang peradilan serta bertambahnya tugas pokok dan fungsi terutama dibidang pelayanan hukum dan pembentukan produk hukum.

Pasal 58 Undang-Undang Nomor 12 Tahun 2011 Tentang Pembentukan Peraturan Perundang-undangan menyatakan bahwa "Pengharmonisasian, pembulatan, dan pemantapan konsepsi Rancangan Peraturan Daerah Provinsi yang berasal dari Gubernur dikoordinasikan oleh biro hukum dan dapat mengikutsertakan instansi vertikal dari kementerian yang menyelenggarakan pemerintahan di bidang hukum". Penempatan harmonisasi (secara horizontal dan vertikal) dalam proses pembentukan perda dilakukan terhadap peraturan perundangan yang lebih tinggi, sederajat, dan pada nilai-nilai yang hidup di masyarakat, serta sesuai dengan kebutuhan masyarakat. Dalam proses ini diperlukan langkah harmonisasi perda sehingga terbentuk perda yang mampu menciptakan kondisi kehidupan yang selaras (law as a tool of social enggineering) bagi masyarakat sehingga terbebas dari kepentingan-kepentingan individu atau kelompok dan golongan-golongan politik kepartaian.

Dalam kamus besar bahasa Indonesia (PEUBI), harmonisasi diartikan sebagai "tahaptahap untuk mencapai suatu keselarasan". Langkah-langkah harmonisasi perda sangat berkaitan erat dengan sistem hukum yang ada, yakni dengan cara:

1. Memperhatikan sistem hukum nasional sebagai masukan (input), dengan memperhitungkan keberadaan unsur-unsur yang sedang berjalan, berupa:

- Substansi hukum yaitu peraturan perundang-undangan, hukum tidak tertulis dan tatanan hukum internal,

- Struktur hukum yaitu kesiapan kelembagaan publik beserta aparatur/ pejabat pemerintah daerah,

- Budaya hukum yang mencakup sikap dan perilaku para pejabat dan warga masyarakat terkait dengan materi peraturan daerah.

2. Memperhatikan realitas keberadaan perda dan penegakannya dalam praktik ketika berseberangan dengan rasa keadilan dan aspirasi yang berkembang di masyarakat.

3. Melakukan penilaian atau evaluasi terhadap hasil yang dicapai berupa terbentuknya perda yang memiliki pengaruh terhadap kehidupan masyarakat.

Ranperda yang telah diharmonisasi diharapkan mampu menjadi Perda yang berdaya guna dan berhasil guna. Namun, rendahnya partisipasi daerah untuk mengirimkan RANPERDA yang termuat dalam Daftar Prolegda untuk diharmonisasi dikarenakan tidak adanya suatu kewajiban yang mengharuskan bahwa RANPERDA itu diharmonisasi 
oleh Kantor Wilayah Kementerian Hukum dan HAM dan Hasil harmonisasi itu dipergunakan sebagaimana mestinya membuat apa yang dicita-citakan oleh UndangUndang Nomor 12 Tahun 2011 Tentang Pembentukan Peraturan Perundangundangan belum sepenuhnya tercapai.

Dalam rapat paripurna Dewan Perwakilan Rakyat Daerah tanggal 15 Agustus 2006 Presiden Susilo Bambang Yudhoyono menegaskan bahwa penyusunan Peraturan Daerah haruslah dikoordinasikan dengan instansi-instansi Pemerintah Pusat. aspek-aspek hukum penjelasan Peraturan Daerah baik yang diprakarsai oleh DPRD, Gubernur, Bupati/Walikota akan menjadi lebih baik jika dikoordinasikan dengan Departemen Hukum dan HAM baik langsung maupun dengan Kantor Wilayah Departemn Hukum dan HAM yang ada di tiap provinsi.

Pasal 98 ayat (1) Undang-Undang Nomor 12 Tahun 2011 Tentang Pembentukan Peraturan Perundang-undangan menyatakan bahwa setiap tahapan pembentukan peraturan perundang-undangan harus mengikutsertakan Perancang Peraturan Perundang-undangan, dimana Perancang Peraturan Perundang-undangan adalah pegawai negeri sipil yang diberi tugas, tanggung jawab, wewenang dan hak secara penuh oleh pejabat yang berwenang untuk melakukan kegiatan menyusun Rancangan Peraturan Perundang-undangan dan/atau instrumen hukum lainnya sesuai dengan ketentuan Peraturan Perundang-undangan.

Pemikiran harmonisasi bermula dari Rudolf Stammler yang mengemukakan bahwa konsep dan prinsip-prinsip hukum yang adil mencakup "harmonisasi" antara maksud, tujuan dan kepentingan individu dengan maksud, tujuan dan kepentingan masyarakat umum. Dengan kata lain, hukum akan tercipta baik apabila terdapat keselarasan antara maksud, tujuan dan kepentingan penguasa (pemerintah) dengan masyarakat. Di sisi lain, Badan Pembinaan Hukum Nasional Kementerian Hukum dan HAM, memberikan pengertian harmonisasi hukum sebagai kegiatan ilmiah untuk menuju proses perharmonisasian (penyelarasan/kesesuaian/keseimbangan) hukum tertulis yang mengacu pada nilai-nilai filosofis, sosiologis, ekonomis dan yuridis.

Harmonisasi Rancangan Perda adalah upaya untuk menyelaraskan, menyesusaikan, memantapkan dan membulatkan konsepsi suatu rancangan Perda dengan Peraturan Perundang-undangan lain, baik lebih tinggi, sederajat maupun yang lebih rendah dan hal-hal lain sehingga tersusun secara sistematis tidak saling bertentangan atau tumpang tindih. $^{3}$ Tujuan pengharmonisasian Rancangan Perda adalah untuk memberikan gambaran yang jelas dalam pemikiran atau pengertian bahwa suatu peraturan Perundang-undangan merupakan bagian integral yang utuh dari keseluruhan sistem peraturan Perundang-undangan sedangkan pengertian Evaluasi Perda disini adalah proses penyajian kesesuaian Peraturan Daerah dengan kepentingan umum dan peraturan Perundang-undangan yang lebih tinggi.

Harmonisasi hukum pada peraturan daerah dengan pendekatan sistem, yakni dengan konotasi sistem sebagai entitas, akan memandang bahwa harmonisasi hukum perda

\footnotetext{
${ }^{3}$ Sofyan Helmi, Upaya Menjadikan Kanwil Depkumham Sebagai Law Center dalam Fasilitasi Pembentukan Perda, http://www.djpp.depkumham.go.id/umum/322-upaya-menjadikan-kanwil-depkumham-sebagailaw-center-dalam-fasilitasi-pembentukan perda.html tanggal akses 21 Juli 2020
} 
merupakan upaya menyeleraskan, menyesuaikan, menyeimbangkan, menyerasikan dan konsistensi unsur-unsur pembentukan perda terhadap tata urutan dan materi perda yang akan disusun. Dengan demikian, upaya harmonisasi ini merupakan conditio sine qua non / usaha bagi terjaminnya kepastian hukum, ketertiban hukum, penegakan hukum dan perlindungan hukum yang berintikan keadilan dan kebenaran.

Dengan demikian secara moral Kantor Wilayah memiliki tanggung jawab atas terjadinya pembatalan peraturan daerah, baik pembatalan yang dilakukan pemerintah pusat maupun Mahkamah Agung. Hal ini disebabkan tugas dan fungsi Kantor Wilayah dalam hal pengharmonisasian Rancangan Perda, kendati tidak ada kewajiban bagi pemerintah daerah untuk melakukan pengharmonisasian rancangan Perda di Kanwil Kementerian Hukum dan HAM.

Kementerian Hukum dan HAM merupakan salah satu kementerian yang dibentuk guna membantu tugas-tugas Presiden (eksekutif) di dalam permasalahan-permasalahan yang menyangkut pelaksanaan tugas pemerintah di bidang hukum, dan juga menyangkut substansi dan sistem hukum serta perkembangannya. Tugas Pemerintahan di bidang hukum mencakup peran yang sangat strategis untuk mengaktualisasikan fungsi hukum, menegakkan hukum, menciptakan budaya hukum, dan membentuk peraturan perundang-undangan yang adil, konsisten, tidak diskriminstif, tidak bias gender serta memperhatikan hak asasi manusia. ${ }^{4}$

Kantor Wilayah sebagai perpanjangan tangan Kementerian Hukum dan HAM berperan sebagai pembina hukum dan sekaligus sebagai koordinator harmonisasi dan sinkronisasi rancangan peraturan perundang-undangan di daerah. Hal ini terlihat dari ketentuan Pasal 2 ayat (3) butir 24 Peraturan Pemerintah Nomor 25 Tahun 2000 yang menyatakan bahwa sebagian kewenangan Menteri Kehakiman dan HAM dilaksanakan oleh Kantor Wilayah Departemen ${ }^{5}$ Kehakiman dan HAM setempat. Tugas dari Kantor Wilayah Kementerian Hukum dan HAM sendiri mencakup hal-hal dibawah ini, yaitu:

1. Melakukan aktualisasi fungsi hukum berupa pembentukan peraturan perundang-undangan di daerah yang adil, konsisten, tidak diskriminatif, dan tidak bias gender;

\footnotetext{
${ }^{4}$ Suhariyono, Peranan Kantor Wilayah Departemen Hukum dan Hak Asasi Manusia Dalam Penyusunan Prolegda, Dalam Bimbingan Teknis Proglam Legislasi Daerah, Jakarta, 2007, hlm. 41.

${ }^{5}$ Berdasarkan Keputusan Menteri Hukum dan Perundang-Undangan RI Nomor : M.12.PR.07.10 tahun 1999 tanggal 30 Nopember 1999 tentang perubahan Nomenklatur Departemen Kehakiman RI menjadi Departemen Hukum dan Perundang-Undangan RI. Selanjutnya berdasarkan surat Sekretaris Janderal Departemen Kehakiman dan HAM RI Nomor : A.PR.08.10-36 tanggal 4 September 2000 tentang perubahan Nama Departemen Hukum dan Perundang-Undangan menjadi Departemen Kehakiman dan HAM RI dengan sendirinya Kantor Wilayah dan Unit Pelaksana Teknis menyesuaikan. Sejalan dengan Perkembangan Ketatanegaraan maka terjadi pengembangan Organisasi dan perubahan nomenklatur menjadi Kantor Wilayah Departemen Hukum dan HAM sebagaimana dimaksud dalam Peraturan Menteri Hukum dan HAM RI Nomor : M-01.PR.07.10 Tahun 2005 tentang Organisasi dan Tata Kerja Kantor Wilayah Departemen Hukum dan HAM RI tanggal 01 tahun 2005. Kemudian, penyebutan nama Departemen di ubah sejak dikeluarkannya Undang-Undang Nomor 39 Tahun 2008 tentang Kementerian Negara, Lembaran Negara Republik Indonesia Tahun 2008 Nomor 166, Tambahan Lembaran Negara Republik Indonesia Nomor 4916.
} 
2. Memperhatikan terlaksananya penghormatan, pemenuhan, dan perlindungan hak asasi manusia;

3. Melakukan kerjasama dengan instansi di daerah dalam melakukan harmonisasi substansi hak asasi manusia di dalam peraturan perundangundangan di daerah;

4. Membantu (konsultatif) pelaksanaan pembentukan peraturan perundangundangan di tingkat daerah dari sisi substansi aturannya.

Keseluruhan tugas dan fungsi Kanwil Kementerian Hukum dan HAM sebagaimana disebutkan diatas merupakan implementasi dan Konsekuensi logis dari pelaksanaan tugas sebagaimana diuraikan diatas sebagai kepanjangan tangan Menteri di daerah, maka kanwil harus serius mempersiapkan diri serta memiliki tenaga hukum yang berkualitas agar dapat yang melaksanakan tugas yang diamanatkan oleh ketentuan diatas. Keberhasilan dan kegagalan pembinaan hukum dan perundang-undangan di suatu daerah berada diatas pundak Kepala Kantor Wilayah.

Terkait dengan banyaknya pembatalan Peraturan Daerah, ${ }^{6}$ Menkumham menyatakan bahwa Kanwil Kementerian Hukum dan HAM ikut bertanggung jawab jika terjadi pembatalan Perda di daerah. Pernyataan tersebut dapat dipahami jika dikaitkan dengan tupoksi kanwil di bidang pengembangan hukum, tetapi tanggung jawab yang dimaksud oleh Menteri Hukum dan HAM tersebut tentu bukanlah tanggung jawab Kanwil secara langsung atas terjadinya pembatalan perda melainkan pertanggungjawaban secara moral. ${ }^{7}$ Hal ini disebabkan posisi Kanwil di daerah memang bukan merupakan bagian dari pemerintah daerah, tidak seperti posisi Kementerian Hukum dan HAM di pusat. Di tingkat pusat, Kementerian Hukum dan Hak Asasi Manusia memang bertugas mengoordinasikan pengharmonisasian, pembulatan, dan pemantapan konsepsi rancangan peraturan perundang-undangan yang berasal dari Presiden sebagaimana disebutkan di dalam Pasal 47 Undang-Undang Nomor 12 Tahun 2011. Kantor Wilayah Kementerian Hukum dan Hak Asasi Manusia di daerah tidak memiliki fungsi koordinasi tersebut. ${ }^{8}$ Fungsi koordinasi dalam rangka pengharmonisasian, pembulatan, dan pemantapan konsepsi Rancangan Peraturan Daerah dilaksanakan oleh biro/bagian hukum Pemerintah Daerah provinsi/ kabupaten/kota. ${ }^{9}$ Lebih lanjut Pasal 98 Undang-Undang Nomor 12 Tahun 2011 menyebutkan bahwa :

1. Setiap tahapan Pembentukan Peraturan Perundang-undangan mengikutsertakan Perancang Peraturan Perundang-undangan.

2. Ketentuan mengenai keikutsertaan dan pembinaan Perancang Peraturan Perundang-undangan sebagaimana dimaksud pada ayat (1) diatur dengan Peraturan Pemerintah.

Ketentuan diatas mengandung makna bahwa peran perancang peraturan perundangundangan sangat dibutuhkan dalam setiap pembentukan peraturan perundang-

\footnotetext{
${ }^{6}$ Tercatat per 29 Maret 2010, dari 1.024 Perda yang disampaikan untuk dievaluasi dari 33 Kabupaten/Kota di Sumatera Utara, 472 di antaranya sudah dibatalkan. Pembatalan tersebut lebih disebabkan karena menimbulkan ekonomi biaya tinggi sehingga akan berdampak menghambat investasi.

${ }^{7}$ Septiyarto Priandono, Op.Cit.

8 Ibid

${ }^{9}$ Ibid
} 
undangan termasuk Perda. ${ }^{10}$ Namun belum semua daerah melakukan harmonisasi seperti Di Kantor Wilayah Kementerian Hukum dan HAM Sumatera Utara. Dalam kurun waktu Juni 2010 sampai saat ini Kanwil telah melakukan harmonisasi rancangan Peraturan Daerah sebanyak 90 Ranperda yang berasal dari Kabupaten/Kota di Sumatera Utara.

Dalam penyusunan Perda, Pemerintah Daerah berpedoman pada Permendagri Nomor 15 Tahun 2006 tentang Jenis dan Bentuk Produk Hukum Daerah, Permendagri Nomor 16 Tahun 2006 tentang Prosedur Penyusunan Produk Hukum Daerah. Di dalam kedua Peraturan Menteri juga tidak disebutkan secara eksplisit tentang peran Kanwil Kementerian hukum dan HAM.

Dalam ketentuan Undang-Undang Nomor 10 Tahun 2004 tentang Pembentukan Peraturan Perundang-undangan tidak diatur sama sekali keterlibatan instansi vertikal dalam hal ini Kanwil Kementerian Hukum dan HAM dalam proses penyusunan peraturan daerah. Pasca diundangkannya Undang-Undang Nomor 12 Tahun 2011 tentang Pembentukan Peraturan Perundang-undangan yang merupakan pengganti UndangUndang Nomor 10 Tahun 2004 peran Kanwil telah dirumuskan, walaupun sifatnya masih terbatas dan pasif menunggu undangan dari pihak yang berwenang dalam pembentukan peraturan daerah baik Pemerintah Daerah maupun DPRD. hal ini disebabkan dalam beberapa ketentuan Undang-Undang Nomor 12 Tahun 2011 disebutkan bahwa dalam Program Legislasi Daerah, pengharmonisasian, pembulatan dan pemantapan dapat mengikutsertakan instansi vertikal, ketentuan ini tercermin dalam beberapa ketentuan yang terdapat dalam Undang-undang tersebut. ${ }^{11}$ Keterlibatan kanwil dapat dilaksanakan selama Pemerintah di Daerah berkenan untuk mengikutsertakan, Kata "dapat" mengandung makna pilihan bagi pemerintah di daerah, boleh mengikutsertakan boleh juga tidak mengikutsertakan dan tidak ada konsekuensi bagi pemerintah daerah apabila tidak mengikutsertakan Kanwil Kementerian Hukum dan HAM.

\footnotetext{
10 Jabatan Fungsional Perancang Peraturan Perundang-undangan berkedudukan di Kanwil Kementerian Hukum dan HAM, yang mempunyai peran: menentukan pilihan-pilihan (alternatif) yang dikehendaki oleh penentu kebijakan; merumuskan substansi secara konsistens atau taat asas; merumuskan substansi yang tidak menimbulkan penafsiran (ambigu); merumuskan substansi yang adil, sepadan, atau tidak diskriminatif; menjamin bahwa peraturan yang dirancang dapat dilaksanakan dengan mudah oleh pelaksana; menjamin bahwa peraturan yang dirancang tidak bertentangan dengan peraturan perundangundangan di atasnya atau melanggar kepentingan umum; menjamin bahwa peraturan yang dirancang dapat memecahkan masalah yang dihadapi oleh penentu kebijakan; menjadi penengah dalam penyelesaian tumpang tindih kewenangan dan pengaturan dalam pembahasan di tingkat antardepartemen atau antarlembaga; melakukan negosiasi atau pendekatan-pendekatan psikologis terhadap penentu kebijakan demi tercapainya tujuan yang diinginkan.

Dikutip dari Bahan Kuliah Diklat Penyusunan dan Perancang Peraturan Perundang-undangan di BPSDM Kementerian Hukum dan HAM RI, Jakarta.

11 Pasal 36 ayat (3) menyebutkan : "Penyusunan Prolegda Provinsi di lingkungan Pemerintah Daerah Provinsi dikoordinasikan oleh biro hukum dan dapat mengikutsertakan instansi vertikal terkait."

Pasal 58 Ayat (2) menyebutkan: "Pengharmonisasian, pembulatan, dan pemantapan konsepsi Rancangan Peraturan Daerah Provinsi yang berasal dari Gubernur dikoordinasikan oleh biro hukum dan dapat mengikutsertakan instansi vertikal dari kementerian yang penyelenggarakan urusan pemerintahan di bidang hukum."
} 
Seharusnya peranan Kanwil Kementerian Hukum dan HAM lebih dari sekedar peran yang terbatas dan pasif menunggu diikutsertakan, akan tetapi merupakan salah satu unsur dari proses penyusunan peraturan daerah, hal ini penting mengingat Kanwil Hukum dan HAM bukan saja memberikan masukan secara substansi terhadap suatu ranperda, namun juga melakukan harmonisasi dengan ketentuan peraturan perundang-undangan yang hirarkinya lebih tinggi, sehingga inkonsistensi antara peraturan daerah dengan Peraturan Perundang-undangan lainnya dapat diminimalisir.

Kebijakan otonomi daerah pada dasarnya dimaksudkan untuk menjadi pemersatu bangsa, oleh karena itu berbagai peraturan daerah yang dibentuk sebagai dasar hukum untuk melaksanakan otonomi daerah dan tugas pembantuan, menampung kondisi khusus daerah dan untuk menjalankan ketentuan peraturan perundang-undangan yang lebih tinggi. Dalam kaitannya dengan Tugas dan fungsi Kanwil bahwa pada dasarnya tugas dan fungsi Kanwil dalam penyusunan peraturan daerah sudah sejalan dengan ketentuan UU Nomor 12 tahun 2011 tentang Pembentukan Peraturan Perundang-undangan, namun keterlibatan Kanwil Kementerian Hukum dan HAM hanya terbatas dan pasif menunggu pemerintah daerah maupun DPRD mengikutsertakan. Padahal peran Kanwil sangat strategis dalam pengharmonisasian rancangan peraturan daerah untuk meminimalisir peraturan daerah yang materi muatannya tidak sesuai dengan ketentuan peraturan perundang-undangan yang lebih tinggi maupun antar peraturan yang sederajat.

Dalam upaya meningkatkan peran Kanwil Kementerian Hukum dan HAM dalam proses penyusunan peraturan daerah perlu disusun suatu aturan untuk pelaksanaan yang mengatur secara rinci mekanisme penyusunan peraturan daerah yang melibatkan Pemerintah Daerah, DPRD maupun Kanwil Kementerian Hukum dan HAM, dengan adanya payung hukum yang komprehensif diharapkan dapat mendorong optimalisasi penyusunan peraturan Daerah yang berkualitas.

Kantor Wilayah Kementerian Hukum dan HAM Sumatera Barat agar lebih aktif lagi dalam mensosialisasikan proses pembentukan peraturan perundang-undangan sesuai prosedur yang diatur dalam Undang- undang Nomor 12 Tahun 2011 tentang Pembentukan Peraturan Perundang- undangan. Sehingga dapat lebih maksimal dalam menjalankan tugas pokok dan fungsinya dalam penyusunan rancangan produk hukum daerah. 


\section{Daftar Pustaka}

Abdul Hakim Garuda Nusantara, 1988. Politik Hukum Indonesia, Jakarta: Yayasan LBH Indonesia

Achmad Ali, 2012, Menguak Teori Hukum (Legal Theory) dan Teori Peradilan (Judicial Prudence) Termasuk Interpretasi Undang-Undang (Legisprudence), Jakarta : Kencana

A.Hamid S. Attamimi, 1997, Materi Muatan Peraturan Perundang-undangan, Majalah Hukum Dan Pembangunan, Jakarta

Amiruddin dan Zainal Asikin, 2006, Pengantar Metode Penelitian Hukum, Jakarta: Rajawali Press

Bambang Sunggono, 2012, Metodologi Penelitian Hukum, Jakarta: Rajawali Press

Bagir Manan, 1992, Dasar-Dasar Perundang-undangan di Indonesia, Jakarta

, 1987, Pembinaan Hukum Nasional, Universitas Andalas

- 2000, Tata Urut Perundang-undangan dan Problema Peraturan Daerah, Jakarta, LP3HET

, 2009, Komentar Atas Undang-Undang Dasar Negara Republik Indonesia Tahun 1945, Jakarta: Sinar Grafika

2011, Perihal Undang-Undang, Jakarta: Rajawali Press

Mahfud MD, 2006, Membangun Politik Hukum, Menegakkan Konstitusi, Jakarta, LP3ES

Maria Farida Indrati, 1998, Ilmu Perundang-undangan (Dasar-dasar dan Pembentukannya), Yogyakarta

Modul Proses Penyusunan Peraturan Perundang-undangan, 2007, Kerjasama Departemen Dalam Negeri dan Lembaga Administrasi Negara

Soehino, 2006. Hukum Tata Negara Teknik Perundang-undangan, BPFE, Yogyakarta.

Ramlan Surbakti, 2009, Politik dan Pemerintahan Indonesia: Demokrasi Deliberatif dan Partisipatif, Jakarta: Masyarakat Ilmu Pemerintahan Indonesia

Samuel P Huntingtong dan Joan Nelson, 1990, Partisipasi Politik di Berbagai Negara Terjemahan, Bandung: Rineka Cipta

Saldi Isra dan Yuliandri, 2004, Penyusunan dan Pengundangan Peraturan Perundangundangan, Analisis Terhadap Rancangan Undang-Undang Tentang Pembentukan Peraturan Perundang-undangan, LAN

Yuliandri, 2007, Asas-Asas Pembentukan Peraturan Perundang-undangan Yang Baik Dalam Rangka Pembuatan Undang-Undang Berkelanjutan, Universitas Airlangga

Undang-Undang Dasar Negara Republik Indonesia Tahun 1945

Undang-Undang Nomor 10 Tahun 2004 tentang Pembentukan Peraturan PerundangUndangan 
Undang-Undang Nomor 12 Tahun 2011 tentang Pembentukan Peraturan Perundangundangan

Undang-Undang Nomor 15 Tahun 2019 tentang Perubahan Undang-Undang Nomor 12 Tahun 2011 Tentang Pembentukan Peraturan Perundang-undangan

Peraturan Presiden Republik Indonesia Nomor 68 Tahun 2005 tentang Tata Cara Mempersiapkan Rancangan Undang-Undang, Rancangan Peraturan Pemerintah Pengganti Undang-Undang, Rancangan Peraturan Pemerintah, Rancangan Peraturan Presiden

Abdul Gani Abdullah, Pengantar Memahami Undang-Undang Dalam Pembentukan Peraturan Perundang-undangan, Jurnal Legislasi Indonesia Vol1. No.2 September 2004

Delfina Gusman, 'Problematika Pembentukan Peraturan Perundang-undangan Di Indonesia". Jurnal Yustisia Vol.19 No.1 Januari-Juni 2012

Gokma Toni Parlindungan, "Prinsip-Prinsip Negara Hukum dan Demokrasi Dalam Pembentukan Peraturan Daerah" Jurnal Respublica Vol.16 No.2 Tahun 2017

Hendrik Hattu, "Tahapan Undang-Undang Responsif", Jurnal Mimbar Hukum, Vol.23 No.2, Juni 2011

Muhammad Suharjono, "Pembentukan Peraturan Daerah Yang Responsif Dalam Mendukung Otonomi Daerah". Jurnal DIH Fak.Hukum UNTAG, Vol.10 No.19 Februari 2014

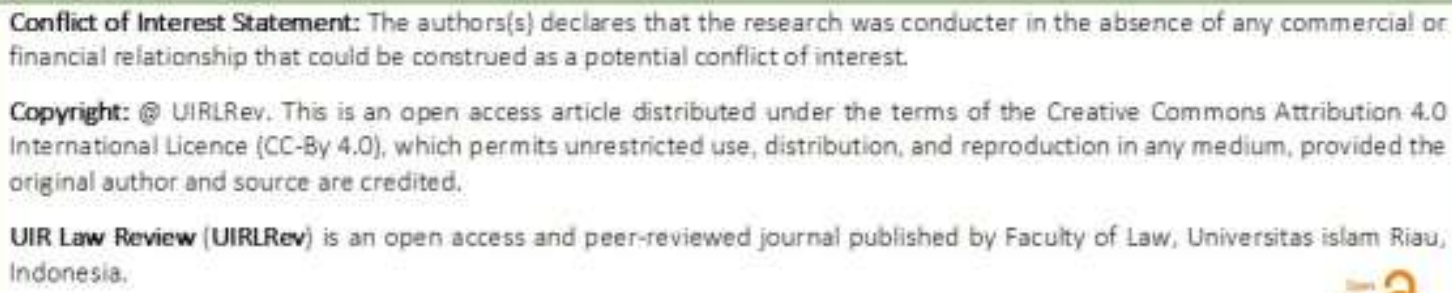

